\title{
THE IMPLICATION OF BRAIN GAIN ON BRAIN DRAIN PHENOMENON IN OVERCOMING THE PROBLEM OF EDUCATED UNEMPLOYMENT IN INDONESIA
}

\author{
Duwi Yunitasari, Khusnul Khotimah, and Moehammad Fathorrazi \\ Faculty of Economics and Business, University of Jember (UNEJ) Jl. Kalimantan No 37, Tegalboto \\ Jember, Jawa-Timur 68121 \\ E-mail: duwiyunita.feb@unej.ac.id
}

\begin{abstract}
The high number of educated unemployment of university graduates is a significant problem in Indonesia. This study aims to find out the effect of brain drain, economic growth, and provincial minimum wage on educated unemployment of university graduates in Indonesia. In this study, we were implementing brain gain on brain drain in Indonesia. This study uses panel data regression that describes the relationship between independent variable and dependent variables. There are two models from the panel data regression method: the Chow test and Hausman Test. The regression model used is fixed-effect model. The data is secondary data collected from Statistical Central Agency (BPS) and National Agency for Placement and Protection of Indonesia Labour (BNP2TKI) in 2014-2018. The results show that brain drain and economic growth influence the educated unemployment of university graduates but the provincial minimum wage does not have a significant relationship with the educated unemployment of University graduates in Indonesia.
\end{abstract}

Keywords: Brain Drain; Economic growth; Provincial minimum wage; Educated unemployment

\section{IMPLIKASI BRAIN GAIN TERHADAP FENOMENA BRAIN DRAIN DALAM MENGATASI MASALAH PENGANGGURAN TERDIDIK DI INDONESIA}

\begin{abstract}
ABSTRAK. Banyaknya pengangguran terdidik lulusan universitas merupakan permasalahan utama di Indonesia. Tujuan penelitian ini untuk mengetahui pengaruh brain drain, pertumbuhan ekonomi dan upah minimum provinsi terhadap pengangguran terdidik lulusan universitas di Indonesia. Dalam penelitian ini mengimplementasikan brain gain terhadap brain drain di Indonesia. Jenis dan metode pada penelitian ini menggunakan regresi data panel yang menjelaskan hubungan variabel bebas dan variabel terikat. Dari metode regresi data panel tersebut terdapat dua model yaitu uji chow dan uji hausman, model regresi yang di gunakan fixed effect model. Data dikumpulkan menggunakan data sekunder dari Badan Pusat Statistika (BPS), dan Badan Nasional Penempatan dan Perlindungan Tenaga Kerja Indonesia (BNP2TKI) dari tahun 2014-2018. Hasil penelitian menunjukkan bahwa brain drain dan pertumbuhan ekonomi mempunyai pengaruh terhadap pengangguran terdidik lulusan universitas sedangkan upah minimum provinsi tidak mempunyai hubungan signifikan terhadap pengangguran terdidik lulusan universitas di Indonesia.
\end{abstract}

Kata Kunci: Brain Drain; Pertumbuhan Ekonomi; Upah minimum Provinsi; Pengangguran Terdidik

\section{INTRODUCTION}

Economic development is a planning process carried out to realize society's prosperity in various ways, such as reducing the amount of poverty and unemployment. Unemployment is a big problem that must be solved now and in the next few years (Wardoyo et al, 2016). Education is essential to invest in human resources. Education creates qualified human resources that can increase its human productivity, and it is expected that university graduates will become young generations who can improve country development, that they can fix various problems that occur in that country. Education is a process that aims to increase skill, knowledge, independence, and the establishment of people personality (Arfida, 2003: 77). However, on the contrary, what happens to educated labor in Indonesia instead takes part in increasing the unemployment rate because the higher level of education will tend to prefer jobs according to their desire and education, and this has an impact on the high level of educated unemployment of university graduates in Indonesia (Islamia, 2017). The higher education level, the higher desire to get a job related to their educational background.

\section{Educated Unemployment}

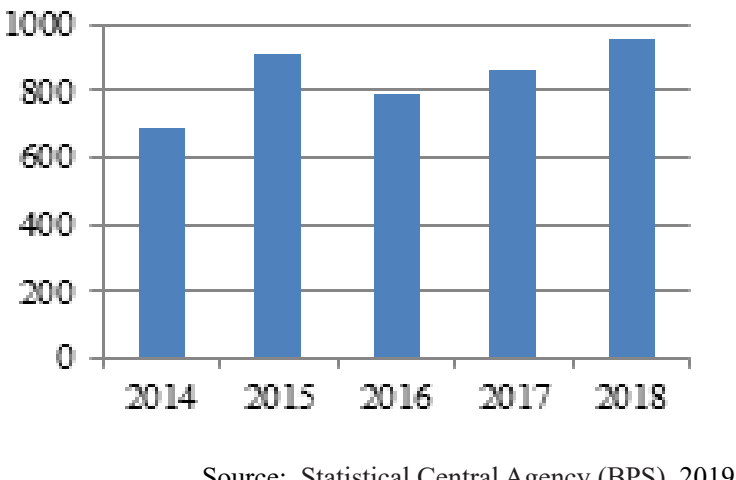

Figure 1. Educated unemployment of University graduates in Indonesia 
Educated unemployment of university graduates in Indonesia continuously experiences fluctuation every year. It is shown by BPS data in Figure 1 in the last five years where in 2014 for about 688,660 people and increased in 2015 by 905,127 people from 2016 to 2017, and in 2018 Educated unemployment of University graduates increased again by 950,553 people. The increase of population and workforce causes competition to work is getting harder; therefore, society has initiative to migrate for finding job opportunities related to their will, especially migrating to abroad. Demography Institute Faculty of Economics University of Indonesia (FEUI), (2007) stated that International Migration is a migration of people from one country to another country. Brain drain is a phenomenon aimed at the migration of skilled, professional, or intellectual people (Saefuloh, 2012). Brain drain is an educated workforces or experts who migrate from their country to another country. The definition of skilled migrant including scientist and researcher, international consultant, manager, artist, operator, athlete, a worker with special qualification, military personnel, and university student (Dodani and La Porte, 2005; and Saefuloh, 2012). Based on the push and pull approach which is the earliest theory of brain drain, the intended push factor is a factor from the country such as income, education, also inadequate education in the country is a factor for someone to migrate to gain knowledge.

This migration is transnational, where migrant workers or nonmigrants who cross the national border either individually or in a group based on economic, politic, or cultural conditions. Three activity components are characterized as crossborder activities, broader transnational activities in the form of cross-border transactions of goods, services, capital, and movement of people, social transaction activities of migrants such as family and community visits. Besides, activities of individual and group involved in a series of cross-border transactions such as travel, exchange of goods and services, delivery and acceptance of business result or money (Patmawati, 2017).

If being compared, international migration will have more influence on the population of a country rather than domestic migration. Domestic migration tends not to affect the population, while international migration will significantly affect the country population because people migrate to other countries. Also, international migration is currently being a problem for many countries, especially developing countries, due to many aspects. So that international migration is one of the country's concerns in order that migration does not harm the country (Yasin, 2015).

Brain drain is a phenomenon that is already familiar in various countries, both developed and developing countries, such as in several countries: China, India, Russia, Greece, and Malaysia. These countries are highly migrating the intellectual labor (brain drain).

However, in fact, these countries realize the importance of brain drain for the economy in their countries so that China and India take advantage of brain drain by creating a policy to take or retract their intellectual labor that is in abroad or "reverse brain," which is changing brain drain into brain gain (Chacko, 2007). Brain gain is a term for educated or skilled workers who migrate to increase their expertise, and after they have been experts, they return to their home country and develop their country (Saefuloh, 2012). The role of the country is needed to provide employment that can absorb educated workers both in terms of amount and income provided. One of the phenomenon is brain drain from Malaysia to Singapore. Professional workers prefer to Singapore because wages are given two to four times higher than in Malaysia (Patmawati, 2017). In asian countries, brain drain has negative impact on employment. It is decreasing the quality and skilled workforce in the country due to higher salaries and better facilities offered by companies in abroad (Patmawati, 2017). While the phenomena of brain drain happens in Indonesia is shown in Table 1.

Table 1. Brain drain in Indonesia (Indonesia migrant worker)

\begin{tabular}{cccccccc}
\hline No & Year & Diploma & $\%$ & Bachelor & $\%$ & $\begin{array}{c}\text { Postgra } \\
\text { duate }\end{array}$ & $\%$ \\
\hline 1 & 2014 & 17.335 & $15 \%$ & 3.956 & $14 \%$ & 179 & $10 \%$ \\
2 & 2015 & 4.685 & $4 \%$ & 1.594 & $6 \%$ & 31 & $2 \%$ \\
3 & 2016 & 2.976 & $3 \%$ & 1.187 & $4 \%$ & 17 & $1 \%$ \\
4 & 2017 & 4.060 & $4 \%$ & 1.298 & $5 \%$ & 24 & $1 \%$ \\
5 & 2018 & 3.081 & $3 \%$ & 1.225 & $4 \%$ & 21 & $1 \%$ \\
Total & & 112.017 & $100 \%$ & 27.611 & $100 \%$ & 1.883 & $100 \%$ \\
\hline
\end{tabular}

Source : BNP2TKI, data processed, 2019 
In Table 1, explaining the number of brain drain in Indonesia, brain drain in Indonesia continuously decreases and fluctuates. It can be seen that the highest number of graduates who migrate abroad is Diploma, which is about 112,017 during 2014-2018. While undergraduate and postgraduate studies decrease by $1 \%$. Date of postgraduate graduates who do brain drain is about 1,883 during 2014-2018. From year to year, there is a decrease in migrant workers who qualify as higher education. The data in Table 1 can increase if the number of educated unemployed is not absorbed in the existing employment. The reverse brain is the implication from two countries, India and China, that implement policies to change brain drain into brain gain, for that Indonesia needs to implement a reverse brain policy to anticipate the increased brain drain. In fact, in addition to positive effect such as better economic growth (remittances), a high number of scientists, and having good relations with other countries. Brain drain also has a negative impact, and it can harm the country, such as lack of an educated workforce and being a backward country. As well known, China is a country that has a very rapid economic growth due to policies that are carried out by doing a reverse brain and being a brain gain that is utilizing its human resources (Zong \& Lu, 2017).

Whereas in the study conducted by Yasin(2015), brain drain in Indonesia were caused by bipolar factors, which are push and pull factors. The push factor is originating from the country, for example, the low allocation of Gross Domestic Product (GDP) for the research and technology sector that causes expert research is not accommodated; therefore, they decide to migrate to another country that can accommodate their research. The problems that occur in terms of GDP allocation can be overcome by the government, considering the government also does the determination of GDP. However, the existence of multidimensional problems that have trade-off sometimes also become an obstacle in increasing the allocation of research and technology, for example, the government increases the alocation in research and technology.

While the pull factor is the existence of research facilities in other countries that are adequate and large allocation of funds for research and technology so that it can attracts scientists. Structural factors, availability of family assets (especially land), potential natural resources, the existence of groups and families. Socio-cultural factors also have an effect but it is more of a function as an economic business space (Setiawan et al, 2016)
The fact that high education is a motive for migrating, and the phenomena of brain drain in Indonesia is increasingly higher. Although other factors such economy also occurs, economic aspects can also occur in unskilled labor or migrant workers who still want to return to their home countries (Yasin, 2015). In line with Chang's study (1992), brain drain in Taiwan is due to educational problems (high school graduates continue to study in abroad) and migration (social, economic, and personal factors which are complex). In Malaysia, high wage in abroad is one of the causes of brain drain, resulting a shortage of skilled workers.

Based on data and empirical facts, the Purposes of the study are:

1. Analyzing the effect of brain drain on educated unemployment of university graduates in Indonesia

2. Analyzing the effect of economic growth on educated unemployment of university graduates in Indonesia

3. Analyzing the effect of wages on educated unemployment of university graduates in Indonesia.

This study not only discuss variables that influence educated unemployment but also tries to provide solutions of brain drain into brain gains.

\section{METHOD}

This type of study uses explanatory. The method used is panel data analysis, which is a merging of time series data (data from one particular individual for a certain period) with cross-section data (data consisting of $n$ observations / $n$ individuals in one particular time) (Hakim, 2014). The scope of this study is that there are 22 provinces in Indonesia. The unit of analysis used in this study is educated unemployment, which is influenced by brain drain variables or abroad migrant workers, economic growth, and the minimum wage in Indonesia during 2014-2018. The data used in this study is secondary data, in which the process of collecting form data or document in government institutions such as national agency for placement and Protection of Indonesian Labour (BNP2TKI) and Statistical Central Agency (BPS).

\section{Panel Data Regression Model}

The regression model in this study uses dependent variable that is Educated Unemployment of University graduates (PT) and independent variables those are total brain drain (BD), Economic Growth (GRDP) and Provincial Minimum Wage 
(PMW). If being written in a mathematical function as follows: (Gujarati, 2013:211)

$\mathrm{PT}=\mathrm{f}(\mathrm{BD}, \mathrm{GRDP}, \mathrm{PMW})$

From its economic model is transformed into econometrics model of panel data regression as follows:

$$
\mathrm{PT}=\alpha \mathrm{i}+\beta 1 \mathrm{BDit}+\beta 2 \mathrm{GRDPit}+\beta 3 \mathrm{PMWit}+\mu \mathrm{it}
$$

Where:

$$
\begin{array}{ll}
\text { PT } & =\text { Educated Unemployment of University } \\
& \text { Graduates } \\
\text { BD } & =\text { Brain Drain } \\
\text { GRDP }= & \text { Gross Regional Domestic Product } \\
\text { PMW }= & \text { Provincial minimum wage } \\
\alpha i & =\text { Constant } \\
\beta 1 \quad \beta 2 \beta 3= & \text { regression coefficient for each variabel } \\
\mu & =\text { residual } \\
\mathrm{i} & =\text { cross-section data } \\
\mathrm{t} & =\text { time series data } 2014-2018
\end{array}
$$

In panel data regression analysis, it can be done by three estimation approach models; those are common effect, fixed effect and random effect models (Widarjono, 2013).

In independent variables and relatedvariables, there are differences in a unit, so the regression equation is firstly transformed into logarithm model (natural logarithm) that is $\log$ on $e$ basis, where $e$ is 2.718, linear in logarithm for variables $\mathrm{Y}$ and $\mathrm{X}$, and can be estimated using OLS regression method (Gujarati, 2013: 211). The equation is as follows:

$\operatorname{LOG~PT}_{\text {it }}=\beta 0+\beta 1 * \operatorname{LOG~BD}_{\text {it }}+\beta 2$

$*$ LOG GRDP ${ }_{\text {it }}+\beta 3 *$ LOG PMW $_{\text {it }}+\varepsilon_{\text {it }}$

\section{RESULT AND DISCUSSION}

Table 2. Results of the Fixed Effect Model Data Panel Regression

\begin{tabular}{lllll}
\hline Variable & Coefficient & Std. Error & t-statistic & Prob \\
\hline C & 15,9639 & 5,127008 & 3,113393 & 0,0025 \\
BD & 0,702324 & 0,145407 & 4,830063 & 0,0000 \\
GRDP & 2,052958 & 0,929881 & $-2,207764$ & 0,0300 \\
PMW & $-0,528429$ & 0,468993 & $-1,126737$ & 0,2630 \\
\hline
\end{tabular}

Source : Data processed, 2019

Based on the calculation of Brain Drain effect, economic growth and provincial minimum wage on educated unemployment of university graduates in Indonesia, based on the result of panel data regression using the fixed-effect method: In table 2, brain drain has a significant positive effect on the number of educated unemployed of university graduates with a probability value $0.0000 * * \mathrm{P}<0.001$, which is less than 0.05 with a coefficient of 0.702324 . The result means that if the number of educated unemployment of university graduates increases by one person each year, the number of Brain Drain also increases by $0.72 \%$ people. Economic growth has a significant negative effect on educated unemployment of university graduates with the probability value $0.0300 * \mathrm{P}<0.030$, which is smaller than 0.05 , and the coefficient value -2.052958 . It means that if the GRDP level increases by 1 percent, the educated unemployment of university graduates in Indonesia will decline by $-2,052 \%$ people. The provincial minimum wage has no significant effect on the educated unemployment of university graduates with the probability value $0.2630 \mathrm{P}<0.2630$, which is larger than 0.05 and the coefficient value -0.58429 , which means that the provincial minimum wage level does not influence the educated unemployment of university graduates in Indonesia.

\section{Simultaneous Test (F Test)}

Table 3. Simultaneous Test Result (F Test)

\begin{tabular}{lccc}
\hline \multicolumn{1}{c}{ R-square } & 0,675455 & $\begin{array}{c}\text { Mean dependent } \\
\text { Var }\end{array}$ & 4,567039 \\
\hline $\begin{array}{l}\text { Adjusted } \\
\text { R-squared }\end{array}$ & 0,583819 & SD.depndent Var & 0,720419 \\
$\begin{array}{l}\text { S.E of } \\
\text { regression }\end{array}$ & 0,64758 & $\begin{array}{c}\text { Sum squared } \\
\text { resid }\end{array}$ & 18,35999 \\
F-statistic & 7,371042 & $\begin{array}{c}\text { Durbin-Waston } \\
\text { Stat }\end{array}$ & 1,770992 \\
$\begin{array}{l}\text { Prob } \\
\text { (F-statistic) }\end{array}$ & 0,000000 & & \\
\hline
\end{tabular}

Source : Data Processed, 2019

In table 3 shows results of the $\mathrm{F}$ test is that the F-statistic probability value is 0.000000 , where the value is smaller than $(\alpha=0.05)$. So that rejecting $\mathrm{HO}$ and $\mathrm{H} 1$ is accepted, which means that the independent variable is brain drain, GRDP and PMW simultaneously has a significant effect on the related variable, which is educated unemployment of university graduates in Indonesia.

\section{Partially Significant Test (t-Test)}

Table 4. t-Test

\begin{tabular}{lllll}
\hline \multicolumn{1}{c}{ Variable } & Coefficient & Std. Error & t-statistic & Prob \\
\hline C & 15,96239 & 5,127008 & 3,113393 & 0,0025 \\
BD & 0,702324 & 0,145407 & 4,830063 & 0,0000 \\
GRDP & $-2,052958$ & 0,929881 & $-2,207764$ & 0,0300 \\
PMW & $-0,528429$ & 0,468993 & $-1,126731$ & 0,2630 \\
\hline
\end{tabular}

Source: Data processed 2019)

The Implication of Brain Gain on Brain Drain Phenomenon in Overcoming the Problem of Educated Unemployment in Indonesia (Duwi Yunitasari, Khusnul Khotimah, and Moehammad Fathorrazi) 
Continuous brain drain has a significant effect on the educated unemployment of university graduates in Indonesia. The economic growth variable has a significant effect on the educated unemployment of university graduates in Indonesia. The minimum wage has no significant effect on educated unemployment in Indonesia. Determination Coefficient (R-squaredtest). Based on Adjusted R-squared test results obtained from the adjusted R-squared that is 0.583819 this means that $58 \%$ of educated unemployed of university graduates are affected by brain drain, economic growth and minimum wage and the rest is influenced by other variables.

\section{Classic Assumption Test Normality test}

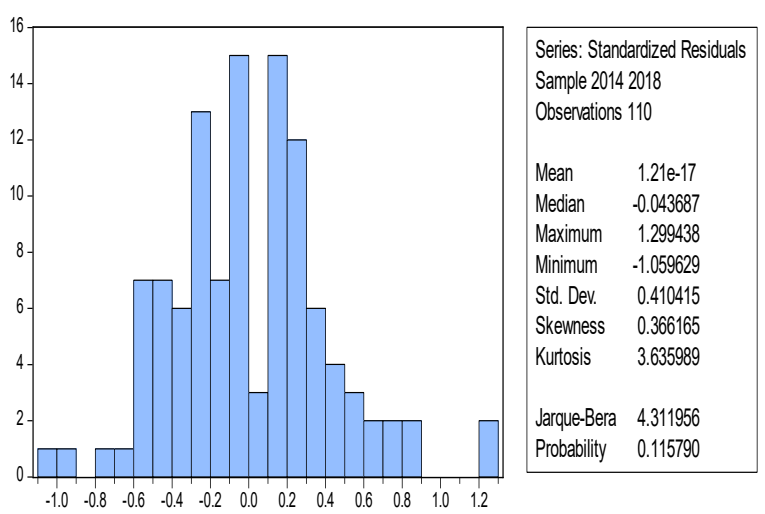

Picture 2. Normality Test Result

Based on probability value $0,115790>\alpha=5 \%$ where it is higher than 0,05 can be concluded that the empirical model is normally distributed.

\section{Multicollinearity Test}

Table 5. Multicollinearity Test

\begin{tabular}{lrrr}
\hline & BD & GRDP & PMW \\
\hline BD & 1,000000 & 0,004458 & \\
& & & $-0,351931$ \\
GRDP & 0,004458 & 1,000000 & \\
& & & 0,499288 \\
PMW & $-0,351931$ & 0,499288 & \\
& & & 1,000000 \\
\hline
\end{tabular}

Source: Data processed, 2019

Table 5 shows the result of the multicollinearity test using a Correlation Test less than 0.80 , where each independent variable does not have a value above 0.80 , meaning that in this study, the result of the multicollinearity test of this model is free from Multicollinearity.

\section{Heteroscedasticity Test}

Table 6. Heteroscedasticity Test Result

\begin{tabular}{llll}
\hline F-statistic & 1,385185 & Prob.F (9,12) & 0,2936 \\
\hline Obs*R-squared & 11,20981 & Prob.Chi-Square (9) & 0,2616 \\
Scented & 5,335485 & Prob.Chi-Square (9) & 0,8041 \\
Explained SS & & & \\
\hline
\end{tabular}

Source : Data processed, 2019

Table 6 is the result of the Heteroscedasticity Test using the White test shows Chi-Square in Obs*R-Squared is 0,2616 higher than $\alpha=0,05$, so this can be concluded that $\mathrm{H} 1$ rejected dan $\mathrm{H} 0$ accepted. It means the regression model is homoscedasticity or no occur heteroscedasticity.

\section{The Effect of Brain Drain on Educated Unemployment of university graduates}

From the result of this study, the brain drain or Indonesian intellectual migration worker has a significant and positive influence on the educated unemployment of university graduates in Indonesia. This means that if educated unemployment of university graduates has increased, it will also result in higher brain drain rates in Indonesia. Brain drain is an educated workforce working in abroad, where the latest education is taken from diploma to postgraduate level. The high level of brain drain is caused by the high supply for labor and the lack of available employment opportunities; therefore, society will take the initiative to migrate abroad for finding work opportunities related to their desires and abilities. Brain drain educated workforce, which is the most important human resource for the country, with a high level of brain drain it can be harmful for the country, which will decrease scientists. This study is in line with (Suwartiyani, 2016) which explains that India is one of the countries that has a high level of brain drain, the impact of the high level of brain drain can harm the country; therefore the Indian government provides several ways to cope with brain drain in India. The creation of new job opportunities can be directed at employment related to industrialization, where this must be followed by an increase in the qualifications of workers so that they are suitable for employment in the industrial sector (Adriani and Wildayana, 2015). Sepriadi (2018) states that high educated unemployment can increase brain drain rates and Greek government effort to prevent intellectual emigration, which explains that Greece is a developing country that sends the highest intellectual employment after India because it was caused in 2008 after the country's economic crisis, Greece experienced the problem of increasing educated unemployment, and thus they choose to migrate to abroad. 


\section{The effect of economic growth on educated unemployment}

The result of this study shows that economic growth has a significant and negative effect on the educated unemployment of university graduates in Indonesia. This means that if the level of economic growth continues to increase, it can reduce the level of educated unemployment of university graduates because if the level of GRDP increases, it indicates that more product or output produced by a region or country, therefore companies will expand the labor supply. This study is in line with the theory of the law of economic growth and unemployment. The law of the Okun (Okun's law) examines the relationship between the unemployment rate and GDP for a country. Where an increase in unemployment in a country will be equivalent to a decrease in GDP by 2 percent (Kuncoro, 2013). This study is in line with Islamia (2017) where the level of economic growth has a significant negative effect on educated unemployment of university graduates in Java, and economic growth is a significant contribution to educated unemployment because high economic growth can encourage economic activity, high economic growth indicates that the company's productivity activity is increasing, that is by producing a high output. So if it happens, the need for labor to produce goods and services will also increase. Because the relationship between unemployment and economic growth is very close where society can produce products and services, so it can be concluded if the unemployment rate increases, it shows that the rate of economic growth is decreasing. This study is in line with Sari (2016) the increase of GRDP will reduce the number of educated unemployed in East Java. The amount of GRDP in East Java itself is supported by the industrial sector, which has an increase of GRDP in every year. The industrial expansion will increase output, which will create many jobs. The result of this study is in line with the opinion Soylu et al. (2018) which states that economic growth and unemployment in eastern Europe have a significant and negative relationship that is if GDP increases by 1 percent unemployment decreased by 0.8 percent in Europe where this study is in line with the theory Okun. The theory states that the higher economic growth rate shows that the unemployment rate is decreasing.

\section{The Effects of provincial minimum wages on educated unemployment of university graduates in Indonesia}

As a result of this study, the provincial minimum wage (PMW) does not significantly influence the educated unemployment of university graduates. This study is not in line with the theory of A.W Philips called Philips Curve theory. Philips curve theory explains that in the short term, there is a negative relationship between an increase of wage or inflation on unemployment because the higher wage level decided, the higher the number of unemployment too (Mankiw, 2000). The theory did not apply to Indonesia's condition in 2014-2018. This happens because wage conditions in Indonesia in the last five years in some provinces are rigid. It is due to the decision of minimum wages by the government that is not in line with the market and demand for an increase of minimum wage. According to Mahyuddin, and Zain, (2016), three factors as cause, are the existence of a minimum wage law decided by the government, the strength of labor union, and related to the efficiency of wage. Moreover, the minimum wage does not affect the amount of unemployment because workers still receive wage given by the company even though the wage is under the standard minimum wage rather than choosing wage in line with minimum wage standard. However, it has an impact on educated unemployment. This study is in line with Hartanto (2017) states that the minimum wage has no effect on unemployment in East Java, wherethe minimum wage that is decided does not have a real relationship on unemployment because it is rigid.

\section{Implications of Brain Gain on the Brain Drain Phenomenon}

Indonesia is a country that experiences brain drain (BNP2TKI, 2019); therefore, it is essential to implement a policy to reduce the level of brain drain by increasing brain gain in Indonesia, that is by doing a reverse brain. Reverse brain policy needs to be implemented with other policies, such as the development of science and technology and establishing cooperative relationships involving business academics and government as well as other actors (Saefuloh, 2012). The result of this study shows that an increase of unemployment indicates that the level of brain drain will increase too. Therefore there should be policy to expand the supply of labor in Indonesia in order that educated workers do not migrate (brain drain), so that high economic growth is a factor that can reduce the level of unemployment because if economic growth rate increases, it will show that more products or outputs produced by the country, the company will expand the supply of labor. In line with the study of Dodani and LaPorte, (2005) states, it is necessary to create knowledge that includes foreign scientists, institutions, and organizations that enable knowledge creation and 
favorable environment. It is expected to contribute to knowledge, skills, and research for their home country by developing collaborative training, program, research projects, and teaching society in their home country. Experience in Taiwan, the Republic of China government has implemented an ambitious program by recruiting Taiwanese trained talents from abroad. Taiwan's successful experience can be emulated by other developing countries in overcoming brain drain problems caused by complex social, economic, and personal (Chang, 1992). Frédéric's study (2014), states that the emigration of educated workers in many developing countries aims to maximize income (around 10\% of the total). So the government needs to provide jobs that accommodate and adequately in terms of income for university graduates, so they do not do brain drain.

The success of this reserve brain has happened in several countries, one of those in India. Some of the factors that become the leading cause of creating reserve brain patterns in India, according to Saefulloh (2012), are: 1. The gradual transition of Indian government policy. This change has created not only the available new jobs in manufacturing and technology but also an increase in various high education institution's reputation in IT and management. Besides, the management of private institutions is no longer complicated by the intervention of Government, which was previously quite dominant. 2. The occurrence of the reverse brain in India is also caused by lower economic conditions in the United States. This condition causes many companies to close their activities, including severing work relationships with an expert. To overcome this problem, the US began making an outsourcing policy by finding a cheaper but highly skilled expert, and it was by utilizing visa expenditures. This opportunity is utilized by professional and business people from India. They flock back to their country as a facilitator between an expert in India and international market network. The next big boom happened when India created IT cities named Indian Silicon Valley, based in Bangalore, where companies such as Hewlett-Packard, IBM, and Microsoft began to open specialized research laboratories in the region. The result is the creation of new forces of transnational workers in the various economic sector, strengthening physical infrastructure and social in Bangalore and its surroundings, and forging and strengthening transnational relations between India and United States. 3. India's success in attracting back its scientists is inseparable from the network of the diaspora, which has continuously maintained, both scientific and social community diasporas.
Some of the significant scientific diaspora owned, for example, Silicon Valley Indian Professional Association (SIPA), Worldwide Indian Network, The International Association of Scientists and Engineers and Technologists of Bharatiya Origin, and the Interface for Non-Resident Indian Scientists and Technologist Program (INRIST). The existence of these institutions makes them obtain great potential sources in carrying out effective and beneficial cooperation of two countries between India as a developing country with various other advanced industrialized countries.

\section{CONCLUSION}

Brain Drain has a significant positive effect on the unemployment of educated unemployment of university graduates in Indonesia. It means that if the number of educated unemployment of university graduates is high, the amount of brain drain will also increase. Economic growth has a significant negative effect on the educated unemployment of university graduates. It means that every economic growth rate has a good relationship with educated unemployment, that is the higher economic growth, the less educated unemployment of university graduates in Indonesia. The provincial minimum wage has no significant and negative effect on the educated unemployment of university graduates.

\section{REFERENCES}

BNP2TKI. the National Agency for Placement and Protection of Indonesia Labour. (2019). Penetapan dan Perlindungan Pekerja Migran (PMI) asal provinsi periode 2011-2018. http:// www.bnp2tki.go.id/. Diakses tanggal 12/12/19.

Adriani, D. \& Wildayana, E. (2015). Integrasi Pertumbuhan Ekonomi dan Penciptaan Kesempatan Kerja Sektor Pertanian di Indonesai. Sosiohumaniora, 17, (3), 269-275. http://dx.doi.org/10.24198/sosiohumaniora. v17i3.8381

Arfida. (2003). Ekonomi Sumber Daya Manusia. Jakarta: Ghalia Indonesia.

Islamia, AN. (2017). Analisis Pengangguran Terdidik Lulusan Universitas di Pulau Jawa Tahun 2008-2016. Yogyakarta: Fakultas Ekonomi Universitas Islam Indonesia.

Chacko, E. (2007). From brain drain to brain gain: Reverse migration to Bangalore and Hyderabad, India's globalizing high tech cities. GeoJournal, 68, (2-3), 131-140. https://doi. org/10.1007/s10708-007-9078-8. 
Chang, S.L. (1992). Causes of brain drain and solutions: The Taiwan experience. Studies In Comparative International Development, 27, (1), 27-43. https://doi.org/10.1007/ BF02687103

Demography Institute Faculty of Economics University of Indonesia. (2007). Dasar-dasar Demografi, p. 116-117, FEB UI.

Dodani, S. \& LaPorte, R.E. (2005). Brain drain from developing countries: How can brain drain be converted into wisdom gain? Journal of the Royal Society of Medicine, 98, (11), 487491. https://doi.org/10.1258/jrsm.98.11.487. Diakses tanggal 4 April 2020.

Gujarati, D. (2013). Dasar-Dasar Ekonometrika (5th ed.). Jakarta: Salemba Empat.

Hakim, A. (2014). Pengantar Ekonometrika dengan Aplikasi Eviews (1st ed.). Ekonosia Fakultas Ekonomi UII.

Hartanto, T.B. (2017). Analisis Pengaruh Jumlah Penduduk, Pendidikan, Upah Minimum Dan Produk Domestik Regional Bruto (Pdrb) Terhadap Jumlah Pengangguran Di Kabupaten Dan Kotaprovinsi Jawa Timur Tahun 20102014. Jurnal Ilmu Ekonomi Terapan, 2, (1), 21-30. https://doi.org/10.20473/jiet. v2i1.5502.

Kuncoro, M. (2013). Mudah Memahami dan Menganalisis Indikator Ekonomi. Yogyakarta: UPP STM YKPN.

Mahyuddin, N., \& Zain, M. M. (2016). Elastisitas Permintaan Tenaga Kerja dan Kekakuan Upah Riil Sektoral di Sulawesi Selatan. Jurnal Agro Ekonomi, 28, (2), 113. https://doi. org/10.21082/jae.v28n2.2010.113-132.

Mankiw, N. G. (2000). Teori Makro Ekonomi (4th ed.). Yogyakarta: Erlangga.

Patmawati, P. (2017). Kebijakan Pemerintah Najib Tun Razak Terhadap Fenomena Brain Drain Dari Malaysia Ke Singapura Tahun 20092013. Jom Fisip, 4, (2), 1-30. https://doi. org/10.1017/CBO9781107415324.004.

Saefuloh, A. A. (2012). Kebijakan reverse brain: mengapa penting dan alternatif pendekatan Jurnal Ekonomi \& Kebijakan Politik, 3, (1), 109-124. http://dx.doi.org/10.22212/jekp. v3i1.170.
Sari N. R. F. (2016). Pengaruh variabel Ekonomi Makro Terhadap Penganguran Terdidik di Jawa Timur 2010-2014. Jurnal Ekonomi Pembangunan, 14, (01), 71-84.

Sepriadi. (2018). Upaya Pemerintah Yunani Mencegah Emigrasi Para Inetelktual Tahun 2008-2017. Yogyakarta: Universitas Muhammadiyah.

Setiawan, I., Sumardjo., Satria, A. \& Tjitropranoto, P. (2016). Studi potensi Brain Gain sebagai Inovasi Regenerasi Pelaku Agribisnis di Dataran Tinggi Cianjur. Sosiohumaniora, 18, (1), 44-50. http://dx.doi.org/10.24198/ sosiohumaniora.v18i1.9356

Soylu, Ö.B., Çakmak, İ. \& Okur, F. (2018). Economic growth and unemployment issue: Panel data analysis in Eastern European Countries. Journal of International Studies, 11, (1), 93-107. https://doi.org/10.14254/2071$8330.2018 / 11-1 / 7$

Statistical Central Agency (BPS). (2019). Pengangguran terbuka menurut pendidikan tertinggi yang ditamatkan.

https://www.bps.go.id/statictable/2009/04/16/972/ pengangguran-terbuka-menurut-pendidikantertinggi-yang-ditamatkan-1986---2020.html. Diakses tanggal 12 Juni 2019

Suwartiyani. (2016). Upaya pemerintah India dalam Menanggulangi Brain Drain Khususnya Dalam Perkembangan Tekhnologi atau Perangkat Lunak (Sofware). Yogyakarta: Universitas Muhammadiyah.

Sari, N.R.F. (2016). Pengaruh Variabel Ekonomi Makro Terhadap Penganguran Terdidik di Jawa Timur 2010-2014. Jurnal Ekonomi Pembangunan, 14, (01), 71-84.

Widarjono, A. (2013). Ekonometrika: Pengantar dan aplikasinya. Jakarta: Ekonosia.

Yasin, M. Z. (2015). Fenomena Brain Drain (Skill Migration) di Indonesia: Analisis Determinan dan Solusi Permasalahan. Surabaya: Fakultas Ekonomi dan Bisnis Universitas Airlangga. .

Zong, L. \& Lu, Y. (2017). Reconceptualization of "Brain Drain." International Journal of Chinese Education, 6, (2), 288-314. https:// doi.org/10.1163/22125868-12340084. 